International Journal of Trend in Scientific Research and Development (IJTSRD)

Volume: 3 | Issue: 3 | Mar-Apr 2019 Available Online: www.ijtsrd.com e-ISSN: 2456 - 6470

\title{
Review on the Development of Road Cleaning and Scrap Collecting Robotic Vehicle
}

\author{
Naveen Kumar' ${ }^{1}$ Ayush Goel ${ }^{2}$, Vipul Verma ${ }^{2}$, Peeyush Kr Gupta ${ }^{2}$, Vishal Gupta ${ }^{2}$ \\ ${ }^{1}$ Assistant Professor, ${ }^{2}$ Student, Department of Mechanical Engineering \\ ${ }_{1,2}$ ABES Engineering College, Ghaziabad, Uttar Pradesh, India
}

\begin{abstract}
How to cite this paper: Naveen Kumar | Ayush Goel | Vipul Verma | Peeyush Kr Gupta | Vishal Gupta "Review on the Development of Road Cleaning and Scrap Collecting Robotic Vehicle" Published in International Journal of Trend in Scientific Research and Development

(ijtsrd), ISSN: 2456-

6470, Volume-3 |

Issue-3, April 2019,

pp.815-817, URL:

https://www.ijtsrd.c

om/papers/ijtsrd23

032.pdf

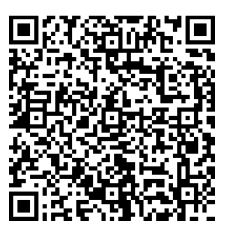

IITSRD23032

Copyright (C) 2019 by author(s) and International Journal of Trend in Scientific Research and Development Journal. This is an Open Access article distributed under the terms of the Creative Commons

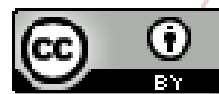

Attribution License (CC BY 4.0) (http://creativecommons.org/licenses/ by $/ 4.0$ )
\end{abstract}

\section{INTRODUCTION}

As indicated by the examinations from different research papers, it is seen that the flotsam and jetsam as residue particles, plastic transfers, wet waste, natural waste, metal jars are cleaned successfully by the cleaning instrument present in the vehicle containing sweepers, suction siphon, scrap authority, electromagnet and so on yet at the same time It requires manual exertion by the laborers to isolate the gathered rubbish and arrange it into dump yard for reusing.

\section{WORKING PRINCIPLE}

The robot trash accumulation framework consists of a lot of turning cutting edges mounted on a pole associated with the engines. The instrument won't work for completely of the vehicle activity and will be operational just for set conditions.

The accumulation framework is structured in such an approach to suit open spots like patio nurseries, transport stands, pathways and so on.

\section{ABSTRACT}

This paper shows continuous examination done on the advancement of Road Cleaning and Scrap Collecting Robotic Vehicle and its uses on different surfaces. As neatness of our condition has its own ideal conditions which makes it a basic ic of research nowadays as it goes under Swacchh Bharat Abhiyan, an activity and paper in like manner gives a compact idea in regards to the end which the maker should be appeared in his/her paper. In the coming days these vehicles will be utilized to diminish contamination and improve tidiness in our area.

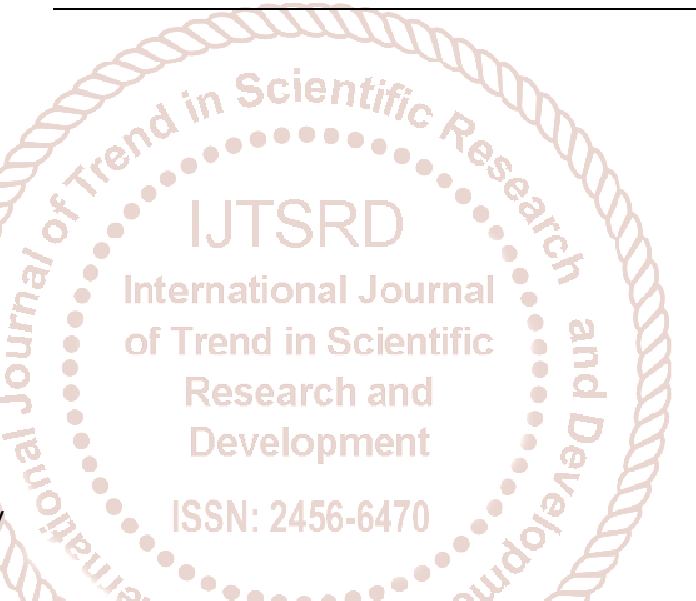

\section{BASIC CIRCUITRY INVOLVED}

Engine driver circuit is utilized for the movement of the vehicle

Power supply for getting adequate capacity to drive the engines

Microcontroller is utilized for controlling the movements of the vehicle

Fundamental structure of the vehicle including gathering tanks

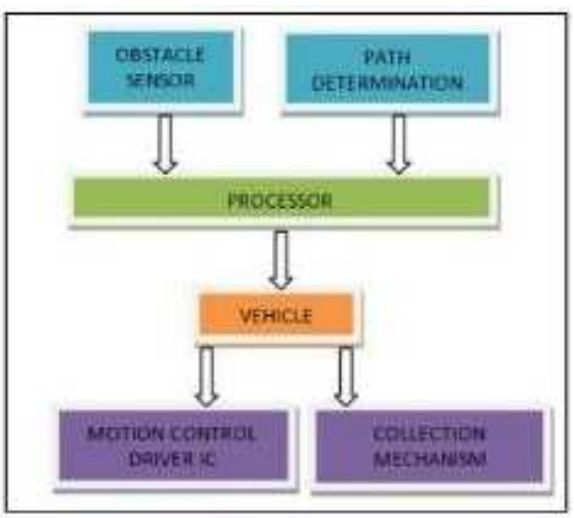


International Journal of Trend in Scientific Research and Development (IJTSRD) @ www.ijtsrd.com eISSN: 2456-6470

\section{LITERATURE REVIEW}

\begin{tabular}{|c|c|c|c|}
\hline AUTHOR & $\begin{array}{l}\text { YEAR OF } \\
\text { PUBLISH }\end{array}$ & TOPIC & FINDING \\
\hline $\begin{array}{l}\text { Nikolai } \\
\text { Romanov, } \\
\text { Michael Dooley, } \\
\text { Paolo Pirjanian }\end{array}$ & 2017 & $\begin{array}{l}\text { ROBOTIC FLOOR } \\
\text { CLEANING APPARATUS } \\
\text { WITH SHELL } \\
\text { CONNECTED TO THE } \\
\text { CLEANING ASSEMBLY } \\
\text { AND SUSPENDED } \\
\text { OVER THE DRIVE } \\
\text { SYSTEM }\end{array}$ & $\begin{array}{l}\text { An automated cleaning framework incorporates a primary } \\
\text { robot body and a majority of cleaning gatherings for } \\
\text { cleaning a surface. The crucial robot body houses a drive } \\
\text { system to cause improvement of the mechanical cleaner } \\
\text { and a microcontroller to control the advancement of the } \\
\text { robotized all the more spotless. The cleaning gathering is } \\
\text { found before the drive framework and every one of the } \\
\text { cleaning congregations is separable from the primary } \\
\text { robot body and every one of the cleaning gatherings has an } \\
\text { extraordinary cleaning capacity. }\end{array}$ \\
\hline $\begin{array}{l}\text { Roger P. } \\
\text { Vanderlinden }\end{array}$ & 2000 & $\begin{array}{l}\text { DEBRIS SUCTIONING } \\
\text { AND SEPARATING } \\
\text { APPARATUS FOR USE } \\
\text { IN A SURFACE } \\
\text { CLEANING VEHICLE } \\
\text { HAVING A } \\
\text { RECIRCULATING TYPE } \\
\text { DEBRIS } \\
\text { SUCTIONING SYSTEM }\end{array}$ & $\begin{array}{l}\text { A refuse Suctioning and Separating gadget for use in a } \\
\text { Surface cleaning vehicle has a reusing type waste } \\
\text { Suctioning System, including a junk Suction head, a } \\
\text { rubbish tolerating and holding holder, and an essential fan. } \\
\text { A junk Separator's mounted on the Surface cleaning } \\
\text { vehicle and having an air narrows for getting rubbish } \\
\text { stacked air into the debris Separator, an air outlet for } \\
\text { crippling Separated air from the refuse Separator. }\end{array}$ \\
\hline $\begin{array}{l}\text { Marcel } \\
\text { Boschung }\end{array}$ & 1989 & $\begin{array}{l}\text { PAVEMENT-CLEANING } \\
\text { VEHICLE }\end{array}$ & $\begin{array}{l}\text { This cleaning vehicle can be utilized for snow leeway by } \\
\text { opening a fold and shutting another fold in an air-outlet } \\
\text { pipe piece and by moving a working switch from a center } \\
\text { position into both of two end positions. }\end{array}$ \\
\hline $\begin{array}{l}\text { Gérard Milly, } \\
\text { Claude D. Le }\end{array}$ & 1989 & $\begin{array}{l}\text { VEHICLE FOR } \\
\text { CLEANING BY LIQUID atic } \\
\text { SPRAYING AND Trend } \\
\text { SUCTION } \\
\qquad 0\end{array}$ & $\begin{array}{l}\text { A vehicle for cleaning surfaces is furnished with a first tank } \\
\text { for putting away cleaning fluid; a gadget for showering } \\
\text { fluid at a first weight and a first stream rate onto the } \\
\text { surface to be cleaned; a gadget for sucking the splashed } \\
\text { fluid towards a second tank; and a gadget for saturating } \\
\text { the surface to be cleaned with fluid at a second weight and } \\
\text { a second stream rate. The second weight is lower than the } \\
\text { principal weight and the second stream rate is lower than } \\
\text { the main stream rate. The showering and sucking gadgets } \\
\text { are situated at the back of the vehicle and the saturating } \\
\text { gadget is situated at the front of the vehicle. }\end{array}$ \\
\hline $\begin{array}{l}\text { Rodney L. } \\
\text { Woodworth }\end{array}$ & 1972 & $\begin{array}{l}\text { CURB TRAVELLING } \\
\text { SWEEPER } \\
\text { VEHICLE }\end{array}$ & $\begin{array}{l}\text { A street sweeper of the three wheel type having forward } \\
\text { and back voyaging wheels is adjusted for the moving of } \\
\text { checks or dividers onto raised surfaces by the } \\
\text { arrangement of lifter wheels substantial versatile among } \\
\text { raised and brought positions down to lift the vehicle and } \\
\text { its voyaging wheels for development onto furthermore, off } \\
\text { the raised surface. }\end{array}$ \\
\hline H. I. Hanson & 1959 & $\begin{array}{l}\text { SUCTION ROAD } \\
\text { CLEANING MACHINE }\end{array}$ & $\begin{array}{l}\text { In a road cleaning vehicle, a vehicle chassis, a main housing } \\
\text { on the chassis, hinged thereto be raised and lowered about } \\
\text { a horizontal hinge axis at its rear end; the main housing } \\
\text { comprising upright front, rear and side walls and top and } \\
\text { bottom walls; partition walls within the main housing } \\
\text { providing a refuse receiving chamber therein comprising a } \\
\text { screening wall proximately spaced from the top wall and a } \\
\text { chamber wall inwardly of the } \\
\text { front wall, providing a space under the top wall and behind } \\
\text { the front wall; a flexible vacuum hose outside the main } \\
\text { housing attached to a side wall and communicating } \\
\text { Through an opening therein with the refuse receiving } \\
\text { chamber at a point adjacent to the underside of the } \\
\text { screening wall. }\end{array}$ \\
\hline T. Harris ET AL & 1954 & $\begin{array}{l}\text { APPARATUS FOR } \\
\text { CLEANING ROAD } \\
\text { SURFACES }\end{array}$ & $\begin{array}{l}\text { It is An apparatus for cleaning a road surface of oil, grease, } \\
\text { and the like deposits these on, coin prising a wheeled } \\
\text { vehicle, a cradle having one end portion thrive of attached } \\
\text { to said Vehicle } 2 \text {.É. the other end thereof adapted to } \\
\text { engage a road Surface to be moved there along as drawing } \\
\text { by Said vehicle, a plurality of Sand blasting IROZZies ad } \\
\text { justly mounted on said Citadel to project there from at an } \\
\text { angle to the road Surface to direct a stream of abrasive }\end{array}$ \\
\hline
\end{tabular}


International Journal of Trend in Scientific Research and Development (IJTSRD) @ www.ijtsrd.com eISSN: 2456-6470

\begin{tabular}{|c|c|c|c|}
\hline & & & $\begin{array}{l}\text { under pressure against the } \\
\text { said road surface to be cleaned. }\end{array}$ \\
\hline $\begin{array}{l}\text { Yoshimori } \\
\text { Fujiwara, } \\
\text { Kazuhiro } \\
\text { Hiratsuka, } \\
\text { Yoshiya } \\
\text { Yamaue, } \\
\text { Hiroaki } \\
\text { Arakawa, } \\
\text { Daizo Takaoka, } \\
\text { Ryuji Suzuki, }\end{array}$ & 1995 & $\begin{array}{l}\text { FLOOR CLEANING } \\
\text { ROBOT AND METHOD } \\
\text { OF CONTROLLING } \\
\text { SAME }\end{array}$ & $\begin{array}{l}\text { This creation relates to a robot for subsequently cleaning } \\
\text { the floor of a room, for instance, inside a moving stock } \\
\text { (railroad vehicles) and to a method for controlling the } \\
\text { proportional. It gives a story cleaning robot having a robot } \\
\text { body which is outfitted with a cleaning segment and which } \\
\text { includes a development instrument controllable for } \\
\text { movement in a perfect course }\end{array}$ \\
\hline $\begin{array}{l}\text { Roger } \\
\text { P.Vanderlinden, }\end{array}$ & 2001 & $\begin{array}{l}\text { MECHANICAL SURFACE } \\
\text { CLEANING VEHICLE } \\
\text { FOR FINE } \\
\text { PARTICULATE } \\
\text { REMOVAL }\end{array}$ & $\begin{array}{l}\text { A mechanical Surface Sweeping vehicle has a circularly } \\
\text { moulded pivoting Sweeping sweeper to impel forwardly } \\
\text { flotsam and jetsam arranged on a reached bit of a Surface } \\
\text { being cleaned, along these lines making a forwardly } \\
\text { impelled Stream of garbage. }\end{array}$ \\
\hline $\begin{array}{l}\text { Louis A. } \\
\text { Pellegrini }\end{array}$ & 1995 & $\begin{array}{l}\text { VEHICLE AND METHOD } \\
\text { FOR COLLECTING } \\
\text { RECYCLABLE WASTE } \\
\text { MATERIAL }\end{array}$ & $\begin{array}{l}\text { This development is coordinated to a truck, trailer or other } \\
\text { vehicle and a technique for gathering recyclable materials } \\
\text { wherein such materials are kept isolated in a holder or box } \\
\text { close to a home or a condo, at that point the holder when } \\
\text { full or in part loaded with the materials, is lifted and } \\
\text { moved to a situation at which it is rearranged and } \\
\text { exhausted of its materials, while still isolated, into } \\
\text { particular compartments on the vehicle }\end{array}$ \\
\hline
\end{tabular}

\section{CONCLUSION}

According to the compositions of various scientists we can presume that the street cleaning and scrap gathering is an extremely monotonous activity and requests physical labour and these mechanical vehicles are the future in the field of tidiness.

According to the exploration led till date there are different such vehicles previously been made yet there is in every case some extent of progress. The officially made vehicles are extravagant and furthermore face challenges in isolation of waste. Henceforth there is a decent degree with respect to the isolation of waste, for example, metallic and non-metallic garbage.

\section{REFERENCES}

[1] Ahmadi, Reza, and John Mamer. "Routing Heuristics for Automated Pick and Place Machines." European Journal of Operational Research

[2] Bhattacharya, S. K., and R. R. Tummala. "Integral passives for next generation of electronic packaging: application of epoxy/ceramic nanocomposites as integral capacitors." Microelectronics Journal 32 (2001) 11-19.

[3] Chalsen, Michael J. "Automatic Chip Placement: One Solution, User-Benefits, and Future Development." IEEE.

[4] 0569-5503 (1991):422-427. Print.

[5] Chen, L. F, and Y. P Hong. "Multi fiber Ceramic Capacitor." Journal of Materials Science: Materials in Electronics, 12.3 (2001): 187-191.

[6] Devoe, Lambert, and Alan Devoe. "Technology and Innovation in Single Layer Capacitors." Microwave Journal, 45.2 (2002): 144-152.

[7] Domonkos, M. T, S Heidger, D Brown, J. V Parker, C.W Gregg, K Slenes, W Hackenberger, Seongtae Kwon, E
Loree, and T Tran. "Sub microsecond Pulsed Power Capacitors Based on Novel Ceramic Technologies." Plasma Science, IEEE Transactions on, (2010): 26862693.

[8] Ho, J, T. R Jow, and S Boggs. "Historical Introduction to Capacitor Technology." Electrical Insulation Magazin. IEEE, 26 (2010): 20-25.

[9] Kishi, Hiroshi, Youichi Mizuno, and Hirokazu Chazono. "Base-Metal Electrode-Multilayer Ceramic Capacitors: Past, Present and Future Perspectives." The Japan Society of Applied Physics. Vol. 42 (2003) pp. 1-15 .Part 1, No. 1, January 2003.

[10] Pan, Ming-Jen, and C.A Randall. "A Brief Introduction to Ceramic Capacitors." Electrical Insulation Magazine, IEEE, 26 (2010): 44-50.

[11] Raboch, Jiri, and Karel Hoffmann. "Parametric Equivalent Circuit of Single Layer Capacitor Mounted in Micro strip Line."Proceedings of the 14th Conference on Microwave Techniques. PAGE:1-3. 2008.

[12] Rogov I. I. , P. M. Pletnev and V. I. Rogov. "A method for rejecting unreliable ceramic capacitor blanks." Russian Journal of Nondestructive Testing. Volume 43. Number 6, 2007. Pages: 410-413. DOI: 10.1134/S1061830907060101

[13] Swartz, S. L. "Topics in Electronic Ceramics." Electrical Insulation, IEEE Transactions on, (1990): 935-987.

[14] Wakino, K., and H. Tamura. "Low-loss Ceramics in Mobile Communications." Encyclopedia of Materials: Science and Technology. Pages 4651-4663 (2001)

[15] Yih-Chien Chen, Shih-Min Tsao, Chang-Shin Lin, ShunChung Wang and Yu-Hua Chien. "Microwave dielectric properties of $0.95 \mathrm{MgTiO3}-0.05 \mathrm{CaTiO3}$ for application in dielectric resonator antenna." Journal of Alloys and Compounds, Volume 471. Issues 1-2. 5 March 2009. 